\title{
Awareness, Importance and Satisfaction with the Library Resources: Survey Results from Pakistan
}

\author{
Intzar Hussain Butt ${ }^{*}$ \\ Ashiq Hussain ${ }^{*}$ \\ Shahzada Qaisar ${ }^{*}$ \\ Jahan Ara Shams ${ }^{* *}$
}

\begin{abstract}
This paper aims at exploring the Master of Philosophy in Education students' awareness about various library resources, their importance and students' level of satisfaction. This paper concerns the librarians, research students and academicians involved in guiding student research. The paper achieves three objectives 1) to understand Master of Philosophy in Education students' awareness of documented library resources 2) explore level of importance given to the documented library resources and 3) to find out students' level of satisfaction about the availability of documented library resources. A conveniently selected sample comprised 100 Master of Philosophy in Education students from a public sector university of Punjab, Pakistan. The data were collected in 2012 through a survey questionnaire which was developed by the researchers and validated by the expert opinions and existing literature. Forty-four library resources were documented in the questionnaire. The response rate was $98 \%$. The data were analyzed by using quantitative approach. It was found that, prior to this survey, the participants were not aware of 14 documented library resources out of which 6 resources have been mentioned as very important by the them. As far as the level of satisfaction about the availability of mentioned resources is concerned, it was very low. This study has highlighted the need for redefining the role
\end{abstract}

* University of Education, College Road, Township, Lahore.

** University of Education, Lahore 
of librarians, functioning of libraries and developing librarian-student partnership in order to facilitate research students.

Keywords: library resources, librarian-student partnership, librarian roles, public

\section{Introduction}

In Pakistan, higher education became the focus of attention with the formation of Higher Education Commission (HEC) in 2001.Realizing the vital role libraries play in the knowledge creation, the HEC has been spending enormous amount for the provision of printed as well as digital learning resources. All the universities have been provided free access to the digital library of the HEC. The university teachers and students can connect to the HEC digital library in order to access a large number of ejournals and e-books. The access to the HEC digital library is available both on campus and outside through Virtual Private Network.

Today, libraries are not just collection of books. Libraries have become outside classroom places for education and research. The connection between education and library is evident from the fact that both have direct relationship with knowledge and its creation. Education provides with knowledge, skills and beliefs through formal institutionalizations while libraries provide access to archives of knowledge, utilizing information resources (Susol, 2009) and providing individual and group study spaces to the students. In the university settings, libraries are next in importance after lecture rooms (Campbell \& Shlechter 1979).

Keeping in view the importance of library resources and service, it is deemed appropriate to look into the Master of Philosophy (MPhil) in Education students' awareness about various library resources and services, their importance and students' level of satisfaction. This paper explores answers to the following question.

1: Were students aware of the listed library resources prior to this survey?

2: Do the students feel that the listed library resources are important for their research?

3: Were students satisfied with each of these library resources, if available in their library? 


\section{Literature Review}

The evidences of the existence of libraries are found from dating back about 2600 B.C. (Lionel, 2002; Barbara, 2010; Kathleen, 2003). Egypt was considered the land of libraries (James, 1954). Even in the earlier years of human civilization, Egypt had an organized collection of library materials, housed in their temples and royal places, etc. (Amen, 1975). Those libraries were maintained and organized by professionally trained and qualified librarian priests. Ramses II (1292-1225 B.C.) contributed to develop the Abydos temple library, Hypostyle Hall (Karnak), a temple library (Luxor), the Abu Simbel rock temple library, the Ramesseum funerary temple library (Thebes) (Zulu, 2008). At the entrance of the library, the Ramses II engraved "the house of healing for the Soul" as a first known library motto (Lutz, 1978).

In the modern era, libraries have become outside classroom places for learning and sharing knowledge. Libraries provide access to archives of knowledge, utilizing information resources (Susol, 2009) and providing individual and group study spaces to the students. In the university settings the libraries are next in importance after lecture rooms (Campbell \& Shlechter 1979). The availability of digital libraries have added to the role of librarians, they are expected to facilitate the research scholars through various services that include access to articles on demand, library orientation sessions, selective dissemination of information, current awareness services, support for publishing, Table of Contents (TOC) alerts, assistance with copyright management, provision of journal articles on demand etc.

Jimenez (2012) stated that "people still have the mindset of a little old lady with a bun surrounded by books telling people to be quiet, but there's been a pretty big shift away from that.” There is a shift in the role of academic libraries because of continuously evolving domain of information production. Libraries are reshaping the academic enterprises by serving as earlier agents in adaptation of digital technologies. Information is being proliferated at indeterminable rates. The libraries, in the developed world, are trying to pave the path for easy access to digital resources. In order to provide real-time and accurate information and meet the needs of multiple users, libraries are being digitized. Libraries also serve its users by guiding and helping to seek their required information through different library resources.

In Pakistan various researchers have explored the satisfaction of students regarding services provided by the libraries in both and public 
and private sectors. A study conducted by Saeed\&Rarnzan (2003) showed that that students show a great degree of satisfaction with the services delivered to them by a private university library. In another study Bashir (1991) studied the resourcefulness of the largest library of Pakistan to satisfy the real needs of its users. He concluded that the library material rate $(41.3 \%)$ was quite less when it was compared with the results of other research studies. Samreen (2006) concluded that a vast majority of the respondents were not satisfied with the efficacy of reference and information services provided by the departmental libraries of University of the Punjab. This was due to the lack of physical resources, nonprofessional attitude, and lack of information in most of the departments of University of the Punjab. In spite of these limitations, the number of frequent visits by researchers in departmental libraries was high. Similar results were also reported by Naz (2006).

Other researchers (Rafi, 2006; Siddique, 2006) concluded that the users were generally satisfied with overall environment of reference section. They were also satisfied with the physical facilities. However lack of latest reference sources was observed and there was need of staffs' training regarding Information\& Communication Technology skills (ICT). Siddique (2006) further commented that orientation sessions were not held by the librarians. The results of another study conducted in Pakistan (Majeed, 1998) showed that only $28 \%$ students were satisfied with the issue return services and $60 \%$ students were pleased with information retrieval system.

\section{Methodology}

\section{Research Design}

This study is descriptive in nature. The data was collected by the researchers, personally, by visiting various Campuses of a public sector university.

\section{Participants of the study}

The population of the study was MPhil students who have finished their course work and now they were about to involve in their thesis work. The data were collected from students who were enrolled in MPhil Education at various Campuses of a public university in Lahore, Pakistan .The sample comprised 100 MPhil Education students, both males and females. The survey questionnaire was personally distributed to all the students who had completed their course work prior to the 
administration of this survey. The lists of students were obtained from the concerned heads of the campuses.

\section{Instrument and data collection}

The data were collected using a 44 items questionnaire. The questionnaire was developed by the researchers and validated by the expert opinions and existing literature on library facilities. The questionnaire consisted of three parts: Awareness, Importance and Satisfaction .The awareness part of the questionnaire required either a yes or no response. The other two parts were based on 5 point Likert scale. Table 1 presents a pattern of the survey questionnaire. One hundred MPhil Education students were requested to participate in the study. The response rate was $98 \%$.

Table 1

Descriptive of the factors awareness, importance and satisfaction

\begin{tabular}{llll}
\hline Factors & $\mathrm{N}$ & Mean & Std. Deviation \\
\hline Awareness & 99 & 1.41 & 0.168 \\
Importance & 99 & 3.60 & 0.728 \\
Satisfaction & 98 & 3.21 & 0.506 \\
\hline
\end{tabular}

Table 1 shows that majority of the services were known to the MPhil students prior to this survey. The further analysis showed that the library resources and services mentioned in the questionnaire were very important for them. As far as participants' level of satisfaction is concerned, as a group, they were to some extent satisfied with the availability of the library resources.

The library resources about which the students were unaware are mentioned in table 2. Prior to this survey, the participants were unaware of 14 out of 42 documented library services. The resources about which the participants were least aware included Library orientation sessions, Selective dissemination of information and Current awareness services. 
Intzar, Ashiq, Shahzada \& Jahan Ara

Table 2

Descriptive of the library resources about which students have shown least awareness, their importance and level of satisfaction

\begin{tabular}{|c|c|c|c|c|c|c|}
\hline \multirow[b]{2}{*}{ Library Resources } & \multicolumn{2}{|c|}{ Awareness } & \multicolumn{2}{|c|}{ Importance } & \multicolumn{2}{|c|}{ Satisfaction } \\
\hline & Mean & S.D & Mean & S.D & Mean & S.D \\
\hline 1. Library orientation sessions & 1.95 & 1.70 & 3.75 & 1.18 & 3.44 & 0.99 \\
\hline 2. Selective dissemination of & & & & & & \\
\hline information & 1.77 & 0.42 & 2.45 & 1.54 & 2.80 & 1.13 \\
\hline Current awareness services & 1.71 & 0.67 & 3.20 & 1.37 & 3.00 & 1.27 \\
\hline Support for publishing & 1.68 & 0.58 & 4.00 & 0.74 & 3.29 & 1.07 \\
\hline Awareness seminars offered & & & & & & \\
\hline by librarian & 1.65 & 0.48 & 3.72 & 1.04 & 3.14 & 1.19 \\
\hline Table of Contents (TOC) & & & & & & \\
\hline E-Newsletter of the library & $\begin{array}{l}1.05 \\
1.65\end{array}$ & $\begin{array}{l}.50 \\
0.58\end{array}$ & $\begin{array}{l}2.85 \\
3.05\end{array}$ & $\begin{array}{l}1.00 \\
1.57\end{array}$ & $\begin{array}{l}2.95 \\
3.05\end{array}$ & $\begin{array}{l}1.12 \\
1.03\end{array}$ \\
\hline Assistance with copyright & & & & & & \\
\hline $\begin{array}{l}\text { management } \\
\text { 9. Workshops offered by }\end{array}$ & 1.65 & 0.59 & 3.46 & 1.31 & 2.99 & 1.29 \\
\hline librarian & 1.58 & 0.50 & 3.43 & 1.30 & 3.43 & 1.19 \\
\hline 10. Online booksellers & 1.57 & 0.50 & 3.30 & 1.19 & 3.25 & 1.05 \\
\hline $\begin{array}{l}\text { 11. Provision of journal articles } \\
\text { on demand }\end{array}$ & 1.56 & 0.50 & 3.77 & 1.03 & 3.04 & 1.23 \\
\hline 12. Video tutorials on Libraries' & & & & & & \\
\hline materials or services & 1.56 & 0.50 & 3.57 & 1.20 & 3.25 & 1.14 \\
\hline 13. Circulation of library material & 1.55 & 0.50 & 3.50 & 1.17 & 3.63 & 1.16 \\
\hline $\begin{array}{l}\text { 14. Assistance trom your } \\
\text { departmental librarian }\end{array}$ & 1.50 & 0.50 & 3.90 & 1.07 & 2.46 & 0.81 \\
\hline
\end{tabular}

The majority of the services mentioned in table 2 were of importance as far as their research work in concerned. The most important service for them was Support for publishing. When asked about their level of satisfaction with the availability of service about which they were unaware prior to this survey, they showed to some extent dissatisfaction. Some of the services were mentioned as not available by the participants.

Table 3 depicts the resources which were familiar to the respondents prior to this survey, their importance and respondents' level of satisfaction. All the respondents were familiar with Google scholar; they deemed it important and were also satisfied with its availability. The top four important resources mentioned by the respondents included reference services, handbooks, dictionaries, encyclopedia etc. in hard form, hard copies of journals, and HEC digital library. Among these 
Awareness, importance and satisfaction with the library resources:

four, the respondents were not satisfied with the availability of reference services and HEC digital library.

Table 3

Descriptive of the library resources about which students have shown awareness, their importance and respondents' level of satisfaction

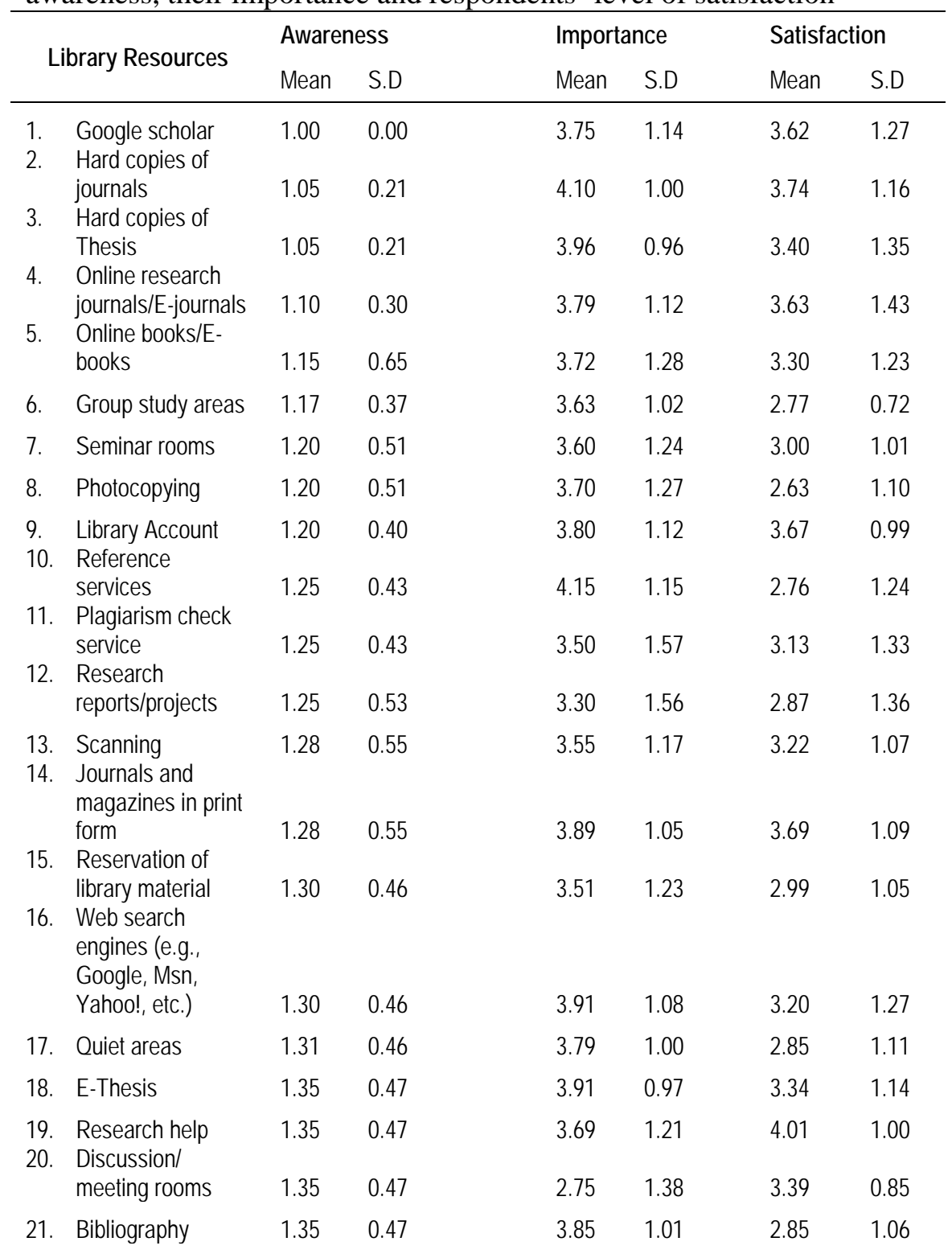




\begin{tabular}{|c|c|c|c|c|c|c|c|}
\hline & management tools & & & & & & \\
\hline 22. & $\begin{array}{l}\text { Handbooks, } \\
\text { dictionaries, } \\
\text { encyclopedias, } \\
\text { etc. in hard form } \\
\text { Electronic }\end{array}$ & 1.35 & 0.47 & 4.15 & 1.01 & 3.70 & 1.19 \\
\hline 23. & magazines & 1.39 & 0.49 & 3.11 & 1.29 & 3.56 & 1.09 \\
\hline 24. & HEC digital library & 1.40 & 0.49 & 4.06 & 0.97 & 3.25 & 1.17 \\
\hline 25. & $\begin{array}{l}\text { Help from library } \\
\text { staff in person or } \\
\text { email } \\
\text { Articles on }\end{array}$ & 1.42 & 0.49 & 3.69 & 0.88 & 3.70 & 0.93 \\
\hline 26. & $\begin{array}{l}\text { Articles on } \\
\text { demand } \\
\text { Video conference }\end{array}$ & 1.44 & 0.49 & 3.89 & 1.09 & 3.00 & 1.14 \\
\hline & rooms & 1.45 & 0.59 & 3.65 & 1.35 & 3.23 & 0.93 \\
\hline 28. & $\begin{array}{l}\text { Social Science } \\
\text { Data Handling } \\
\text { Services }\end{array}$ & 1.45 & 0.50 & 3.86 & 1.26 & 2.90 & 1.09 \\
\hline
\end{tabular}

The other resources about which respondents were aware prior to this survey but were dissatisfied with their availability included photocopying, group study areas, bibliography management tools, quiet areas, research reports/projects, social science data handling services, reservation of library material, articles on demand, seminar rooms, plagiarism check service, web search engines, scanning, video conference rooms, online books/e-books, e-thesis, discussion/meeting rooms, and hard copies of thesis.

\section{Results}

This study has found that respondents were unaware of 33\% of the documented library resources. The respondents have mentioned 79\% of the documented library resources as important for their research. The respondents have shown dissatisfaction about the availability of the $40 \%$ of the documented library resources. The respondents mentioned some of the library resources as not available.

The results have highlighted that the respondents were aware of most of the documented library resources. Majority of the documented resources were of importance for the respondents as far as their research is concerned. The respondents were satisfied with the availability of more than half of the documented resources. 
A closer look at the resources about which the respondents have shown low level of satisfaction reveals that the role of libraries and librarians needs to be redefined. The respondents mentioned the importance of seminar rooms and group study areas, alongside quiet areas, which in general are not available in the present structure of libraries. The importance of on-demand journal articles is also highlighted by the respondents. The respondents have also highlighted the importance of librarians' facilitation in plagiarism check, awareness seminar, copy right management and access to digital resources. The role of librarians as people who issue and return books and keep silence in a large reading area may not suffice the need of the day. There should be a close liaison between the research students and librarians so that the research students could finish their work without delays.

\section{Discussion}

The main objective of this study was three fold 1) to explore students' awareness regarding listed library resources prior to this survey, 2) importance of listed library services and 3) students' satisfaction with the listed library resources. The prior researches conducted in Pakistan have hardly looked into the types of services provided by the Pakistani libraries. Currently most of the libraries in Pakistan are providing issue and return services as their major responsibility. Since many Pakistani libraries are working in old fashioned mode, the users are not aware of the service they can expect from them. The respondents were not aware of $33 \%$ of the documented library services which are being offered by the libraries in the developed world. As far as importance of the documented library resources is concerned, $79 \%$ of them were deemed important for research. The respondents have shown dissatisfaction about the availability of the $40 \%$ of the documented library resources. These results were in accordance with the other research conducted in Pakistan regarding satisfaction with the library services (Bashir, 1991; Samreen, 2006; Rafi, 2006 \&Siddique, 2006).

\section{Conclusion}

It is concluded that students were aware of most of the library facilities. The respondents were dissatisfied with the availability of the documented library resources. There is a need to redefine the role of 
librarians and functioning of libraries in the context of public sector of Pakistan. In order to maintain readership, the librarians will have to offer more than issuing and receiving books and keeping silence in the reading areas. 
Awareness, importance and satisfaction with the library resources:

\section{References}

Amen, M. M. (1975). "Egypt, libraries encyclopedia of library and information science. New York: Marcel Dekker, 7, pp. 574-88.

Barbara, K. (2010). History magazine. Retrieved from http://www.history-magazine.com/libraries.html.

Bashir, S. (1991).Measurement of Book Availability at the Punjab University Library. (Unpublished master's thesis), University of the Punjab, Lahore.

Campbell, D. E. \&Shlechter, T. M. (1979). Library design influences on user behavior and satisfaction. The Library Quarterly, 49(1), 264. Retrieved from http://www.jstor.org/stable/4307048

James, G. G. M. (1954). Stolen legacy: Greek philosophy is stolen Egyptian philosophy. New York: Philosophical Library (reprinted 1976 by Julian Richardson Associates, San Francisco).

Jimenez, M. (2012).Libraries offer more than just books. Retrieved from http://www.vvdailypress.com/articles/victor-36502-bookslibraries.html

Kathleen, M. (2003). "Clay cuneiform tablets from ancient Mesopotamia to be placed online". Retrieved from

http://www.berkeley.edu/news/media/releases/2003/05/06_tablet .shtml.

Lionel, C. (2002). Libraries in the ancient world. Yale University Press. p. 3.

Lutz, C. E. (1978). The oldest library motto. Library Quarterly 48(I). pp. 36-39.

Majeed, S. (1998).Evaluation of reader services of the Punjab University library. (Unpublished master thesis) University of the Punjab, Lahore. 
Naz, Z. (2007). Use and Usability of OPAC in Punjab university library a case study. (Unpublished master's thesis).University of the Punjab, Lahore.

Rafi, S. (2006).An Appraisal on reference and Information ( $R$ and I) Services of Quaid -e-Azam library; A Case study. (Unpublished master's thesis).University of the Punjab, Lahore.

Saeed, H., \&Ramazan, M. (2003). Student's use of the library at Lahore University of management sciences: A Survey. Pakistan Library Bulletin 34(1) 12-16.

Siddique, A. (2006). Status of the services of the information resource center, University of the Punjab. (Unpublished master's thesis).University of the Punjab, Lahore.

Samreen, A. (2006). Researcher's Perceptions and problems regarding reference and information services of the instructional libraries of the University of the Punjab: an analytical survey. (Unpublished master's thesis) University of the Punjab, Lahore.

Šušol, J. (2009). Higher education and the academic library: Perspectives for Slovakia. EDUCAUSE Review, 44(4), pp. 66-67. Retrieved from http://net.educause.edu/ir/library/pdf/ERM09410.pdf

Zulu, I.M. (2008). The ancient kemeticroots of library and information science. Center for Afro-American Studies, University of California Los Angeles.

Received on: 30.01 .2015

Revised on: 28.2.2016

Accepted on: 30.03.2016 